\title{
Optimization of Lecturer Performance Impact on Graduates' Competence through Campus Environmental Support as Intervening Variables in Private Campus Medan City
}

\author{
Ami Dilham ${ }^{1 *}$, Yulinda ${ }^{2}$, Fivi Rahmatus Sofiyah ${ }^{3}$ \\ ${ }^{1}$ Universitas Sumatera Utara \\ ${ }^{2}$ Universitas Sumatera Utara \\ ${ }^{3}$ Universitas Sumatera Utara \\ Email:ami.dilham@usu.ac.id
}

\begin{abstract}
In the era of the COVID-19 pandemic, all learning is done online. The policy of canceling all educational activities adopted by many countries, including Indonesia, has forced the government and related institutions to propose alternative education procedures for students and students who cannot be educated in educational institutions. Many universities at the beginning of the online learning process experienced various problems running it, as well as Private Universities (PTS). PTS are required to further improve the quality and quality of their education so that they are able to compete and even equal with State Universities (PTN). The purpose of this study was to analyze the influence of the family environment, university environment, government support on graduate competence through lecturer performance. This study sees 9 private universities as research objects where there are 205 samples. Data analysis in this study using SmartPLS. As for the results of this study, it is known directly that the family environment, university environment, government support and lecturer performance on graduate competence and indirectly it is known that lecturer performance is able to mediate all independent family environment, university environment, government support on graduate competence.
\end{abstract}

Keywords: Lecturer Performance, Graduates' Competence, Campus Environmental Support.

\section{INTRODUCTION}

Education is an endless problem to be researched from time to time. A country will advance if it is supported by a superior education, competitive, and capable of creating quality human resources that are reliable and can be used as the basic driver of any such State development dimension (Sadikin and Afreni, 2020). The impact of the Corona virus disease 2019 (Covid-19) pandemic is now starting to penetrate the world of education, including in Indonesia (Jamaludin, 2020). This was done to prevent the spread of Covid-19. It is hoped that educational institutions will not carry out activities as usual; this can reduce the spread of Covid19. Countries exposed to the disease have done the same thing, implementing lockdown or quarantine policies to reduce the interaction of many people who can be exposed to the spread of Covid-19. The spread of Covid19 has had a profound impact on the world economy. The world economy has begun to recede, but now the education sector is feeling this impact. The policy of canceling all educational activities adopted by many countries, including Indonesia, has forced the government and related institutions to provide alternative educational processes for students and students who are unable to conduct educational processes in educational institutions (Anugrahana, 2020).

Many universities at the beginning of the online learning process experienced various problems running it, as well as Private Universities (PTS). PTS are required to further improve the quality and quality of their education so that they are able to compete and even equal with State Universities (PTN). Private universities in Medan City also have to face this where the initial obstacles when the online learning process is carried out are: there are still some students and lecturers who have not mastered the online lecture process using applications that have been set by the campus, the next obstacle is when students decide to go home to their hometown 
which causes no internet signal and if there is it is not as strong as in the Medan city area so that it inhibits the students themselves from participating in the online study and the last obstacle faced is the large amount of costs that must be incurred by students and lecturers to conduct online lectures .

Many factors affect the competence of graduates in the current pandemic era, one of which is the learning environment. The learning environment consisting of the family environment, campus, and community environment should be able to synergize and be coherent with one another, because with the establishment of a communication system that is between the foundation and the rectorate, there will be a learning environment that supports learning activities for students. Students will feel comfortable and safe, if their learning environment is supportive in improving learning achievement. Government support during this pandemic is also one of the aspects that encourage the improvement of student competencies. With the policy in this pandemic era, learning activities are carried out from home and require internet access in learning so that support from the government is needed so that the student learning process runs well in the campus environment.

Universities that have qualified lecturers will be in great demand by the public at this time and in the future. Universities that do not want to keep up with current and future changes will be abandoned by the community, sooner or later will experience a setback, which will eventually experience the closure of the university (Firman and Rahman, 2020). Lecturers as the key to educational success are strongly influenced by all existing educational resources. Therefore, to create things that affect lecturer performance, including factors related to intellectual abilities, factors related to organizational learning, factors related to competence, job satisfaction and work motivation (Herliandry, 2020).

Referring to various existing studies, it is stated that the online learning system implemented in the midst of the Covid-19 pandemic has various obstacles, including limited internet quotas and the unfamiliarity of educators and students in applying it. So there needs to be a special effort that is more leverage to overcome this problem from all parties (Abidin and Arizona, 2020). In addition, it was also mentioned that the main problem in distance learning during this pandemic lies in the unavailability of facilities, knowledge and lack of experience. This requires time to adapt and causes delays in the learning process, as well as differences in regional conditions that have not been fully accessible by the internet. Therefore, it is necessary to update the educational model that is in accordance with the pandemic conditions but does not have an impact on the learning process Saleh (2020). It was also stated that the obstacle was that parents had to add more time to accompany their children. Meanwhile, in terms of teachers, teachers become technology literate and are required to learn many things, especially onlinebased learning (Anugrahana, 2020). It takes analysis from PTS to take the right steps. As is known, the main driving force for PTS is the number of students who are still active and carry out the lecture process. If there are fewer students, there is a possibility that the PTS will not be able to carry out the educational process because it is not in demand by new students. The success of PTS running online lectures when the lecture process is carried out at home is a good first step to welcome the New Normal.

\section{LITERATURE REVIEW}

\subsection{Competence of Graduates}

According to Long et al (2016), the quality of education can refer to the quality of processes and product quality. An education is called quality in terms of the process (which is also strongly influenced by the quality of the input) if the process and learning take place effectively, and students experience a meaningful learning process, supported by reasonable resources (human, funds, facilities and infrastructure). Therefore, systematic intervention is given to the process, thus providing a convincing quality assurance.

According Muzenda (2013), the result of an education called quality in terms of products, if it has one or more of the following characteristics: (1), Students demonstrate mastery level high to tasks ( learning tasks ) to be mastered in accordance with educational goals and objectives including academic learning outcomes expressed in learning outcomes (internal quality); (2) The results of education are in accordance with the needs of students in their lives so that by learning students not only know something, but can do something functional for life; (3) The results of education are appropriate or relevant to the demands of the environment, especially the world of work. From this point of view, relevance is one aspect of indicators and quality. Given the multidimensional and multi-criteria nature of the quality of education, in order to achieve this, we are required to place our position clearly.

\subsection{Lecturer Performance}

Lecturer performance has certain specifications. Lecturer performance can be seen and measured based on specifications or competency criteria that must be possessed by each lecturer. In relation to the performance of lecturers, the form of behavior in question is the activities of lecturers in the learning process. In relation to the performance of lecturers, the form of behavior in question is the activities of lecturers in the learning process. Lecturer performance includes several dimensions, namely: (1) quality of work ( quality of work ); (2) timeliness ( promptness ); (3) initiative (initiative); (4) the ability (capability), and (5) communication (communication)[10]. These five aspects can be used as a measure in conducting an assessment of a person's level of performance.

According to (Abidin and Arizona, 2020), performance is basically what lecturers do and/or don't 
do. In contrast to higher education organizations, the assessment or evaluation of lecturers is a way to determine the influence of lecturers' teaching on students. While the quality of the performance of lecturers can be seen from the implementation of their duties and responsibilities as lecturers, both in the fields of education and learning (teaching), research, as well as community service, as well as activities that support the tridharma. Therefore, in an effort to realize the quality of lecturer performance as expected by all parties, it is time for the relevant higher education institution and other related parties to build a more effective and productive system of lecturer coaching (academic supervision).

Human resource performance is a term that comes from the word or (work performance or actual achievement achieved by someone). Performance is the result of a person's overall during a certain period in executing tasks, such as standard work, the target or targets or criteria that have been determined in advance and agreed upon Indahri (2020). Gunawan (2020), performance is a record of the outcome resulting from the function of a particular job or activity during a specific time period. Gaffar and Septyandi (2020), lecturer performance is the result of work during a certain period compared to various possibilities, such as standards, targets/targets or criteria that have been mutually agreed upon. According to Jamaludin (2020) states that the performance of Human Resources is a term of the word Job Performance or Actual Performance is the result of work by the quality and quantity achieved by the faculty in carrying out their duties in accordance with the responsibilities given to the lecturer.

\subsection{Family environment}

According to Abidin and Arizona (2020), the educational environment includes: (1) the family environment, (2) the school environment, and (3) the community environment. The three environments mentioned above are often referred to as the tricenter of education that will affect humans in various ways. To conduct further discussion about the contribution and role of the family in influencing the learning process and child development, it is necessary to study the notion of the family environment. The definition of the family environment comes from the words environment and family. According to Webster's New Collegiate Dictionary the notion of the environment is a collection of all conditions and external influences on the life and development of an organism. Meanwhile, the definition of family according to Emiyati and Harming (2020) is a primary grouping consisting of a small number of people due to marital relations (relationships according to the mother's line) and blood. The family can be in the form of a nuclear family (nucleus family: father, mother and children), or an extended family (beside the nucleus, there are other people: grandparents, siblings/in-laws, maids, and others).

\subsection{Campus environment}

According to the Dai (2020) campus environment is understood as a formal educational institution, which is where learning activities take place, science is taught and developed to students. Meanwhile, according to the National Disciplinary Movement (GDN), the campus environment is defined as an environment where students are familiarized with the values of campus discipline and the values of learning activities in various fields of study that can seep into their conscience (Hermansyah, 2020). Based on the two definitions of the campus environment above, it can be concluded that the campus environment is an environment where students' teaching and learning activities take place and are accustomed to the values of campus discipline and the values of learning activities in various subjects. According to Shahzad et al (2020), the campus functions: First is to help families in the education of their children on campus. Campuses, lecturers and other educators through their legal authority try to carry out their duties. The second is to provide complete knowledge, skills and attitude values according to what is needed by children from different families. Meanwhile, according to Fredy et al (2020), campus functions include the following: (1) Campus prepares children for a job, (2) Campus provides basic skills, (3) Campus opens opportunities to improve fate, (4) Campus provides development personnel, (5) Campus helps solve social problems, (6) Campus transmits culture, (7) Campus forms social people, and (8) Campus is a tool for transforming culture.

\subsection{Government Support}

The government as a state administrator in the field of education, as mandated by the National Education System Law, 2003 that the government has the right to direct, guide, assist, and supervise the implementation of education, and is obliged to provide services and facilities for providing quality education for every citizen without discrimination. The government is also obliged to guarantee the availability of funds for the implementation of education for every citizen from the age of seven to the age of fifteen. More than that, the opportunities for parents/citizens and community groups are still very wide. Human resource development necessary for every citizen of Indonesia has a decent education and to develop the skills acquired in education can be channeled to the Government and to compete with the workers - workers from inside and outside the country. In the country itself, natural resources are abundant, but the abundance of natural resources is not accompanied by the abundance of Indonesian human resources itself. Thus, the abundant natural resources were managed by foreign parties and Indonesia only received a few percent of the profits from processing these natural resources. This was a slap in the face for the Indonesian people, especially for the government. For this reason, human resource development needs to be increased to the proper level. However, in increasing existing human resources, the government must play an active role in its 
improvement, namely in the education aspect. Because, proper and good education will support Indonesian human resources. For this reason, according to Sharma et al (2020) there are several forms of the government's role in improving education, namely the role as a public servant, as a facilitator, as a companion, as a partner and acting as a funder. for more details on the roles of government in education, namely: 1) Role as a public servant. The government acts as a public servant in education, namely the government serves the needs of the community regarding education. The government prioritizes the community to be served so that the education development of each community can be even better. 2) Role as facilitator. The government acts as a facilitator, namely the government as a place provider or provider of facilities for education. Having a role like this the government should be able to mingle in the community, listen to the aspirations of the community regarding the existing school facilities in the area and really check the truth of public complaints about the lack or need for improvement of facilities. 3) Role as a companion. The government in addition to having the main task of being a public servant, but the government has a duty.

\section{RESEARCH METHODS}

This type of research is descriptive quantitative research. According to Sugiyono (2017), research that aims to describe the characteristics of a situation or object of research. The nature of this research is explanatory research, namely research that intends to explain the position of the variables studied and the relationship between one variable and another variable, Sugiyono (2017). The location of this research was carried out at a private university in Medan City, North Sumatra Province. The private universities studied in this study consisted of 9 private universities where the determination of the sample was based on accreditation from the faculty, length of establishment and number of students. Data processing using SmartPLS. Sampling uses the theory of the [20] which is where the number of questions is $x 5$, where the number of questions in this study is 41 x $5=205$ which is then carried out proportional random sampling to 9 PTS as follows:

Table 1. List of PTS in North Sumatera

\begin{tabular}{|c|l|c|c|c|}
\hline $\begin{array}{c}N \\
0\end{array}$ & \multicolumn{1}{|l|}{$\begin{array}{c}\text { University } \\
\text { Name }\end{array}$} & Population & $\begin{array}{c}\text { Calculatio } \\
n\end{array}$ & Total \\
\hline \multirow{2}{*}{1} & $\begin{array}{l}\text { Islamic } \\
\text { University of }\end{array}$ & 282 & $\begin{array}{c}282 x \\
(205 / 334\end{array}$ & 17 \\
& Sumatera & & $2)$ & \\
\hline
\end{tabular}

\begin{tabular}{|c|c|c|c|c|}
\hline 2 & $\begin{array}{l}\text { HKBP } \\
\text { Nommensen } \\
\text { University }\end{array}$ & 228 & $\begin{array}{c}228 x \\
(205 / 334 \\
2)\end{array}$ & 15 \\
\hline 3 & $\begin{array}{l}\text { Muhammadiya } \\
\text { h University of } \\
\text { North Sumatra }\end{array}$ & 893 & $\begin{array}{c}893 x \\
(205 / 334 \\
2)\end{array}$ & 55 \\
\hline 4 & $\begin{array}{l}\text { Panca Budi } \\
\text { University of } \\
\text { Development }\end{array}$ & 481 & $\begin{array}{c}481 x \\
(205 / 334 \\
2)\end{array}$ & 29 \\
\hline 5 & $\begin{array}{l}\text { Indonesian } \\
\text { Methodist } \\
\text { University }\end{array}$ & 346 & $\begin{array}{c}346 x \\
(205 / 334 \\
2)\end{array}$ & 21 \\
\hline 6 & $\begin{array}{l}\text { Dharma } \\
\text { Agung } \\
\text { University }\end{array}$ & 253 & $\begin{array}{c}253 x \\
(205 / 334 \\
2)\end{array}$ & 16 \\
\hline 7 & $\begin{array}{l}\text { Medan } \\
\text { University Area }\end{array}$ & 385 & $\begin{array}{c}385 x \\
(205 / 334 \\
2)\end{array}$ & 24 \\
\hline 8 & $\begin{array}{l}\text { Saint Thomas } \\
\text { Catholic } \\
\text { University }\end{array}$ & 125 & $\begin{array}{c}125 x \\
(205 / 334 \\
2)\end{array}$ & 7 \\
\hline 9 & $\begin{array}{l}\text { Dharmawangs } \\
\text { a University }\end{array}$ & 349 & $\begin{array}{c}349 x \\
(205 / 334 \\
2)\end{array}$ & 21 \\
\hline & Amount & 3,342 & & 205 \\
\hline
\end{tabular}

\section{RESEARCH RESULT AND DISCUSSION}

\subsection{Characteristics of Respondents}

Table 2. Respondent's Descriptive

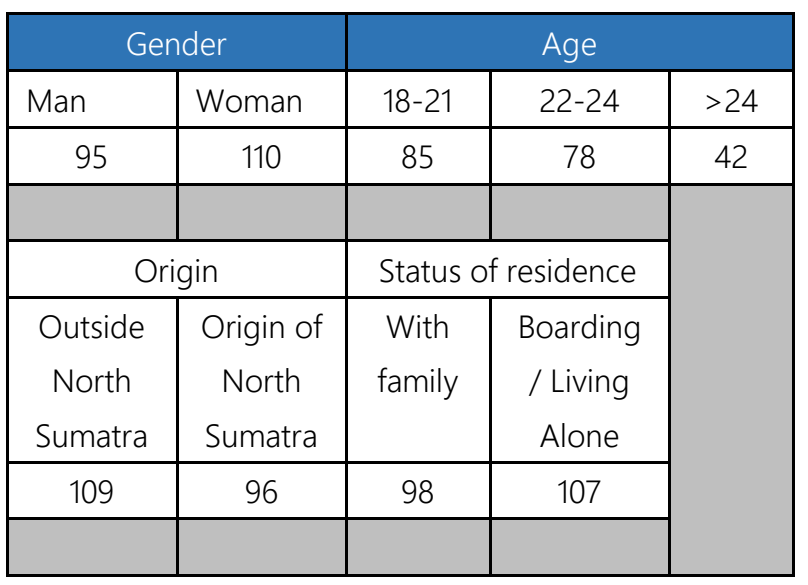


Based on Table 2 , it is known that there are 95 male respondents studying at 9 private universities and 110 female respondents, while for the age group it is known that the dominant respondents are 18-21 years old and for regional origin, most of the respondents come from outside Sumatra. North and the dominant respondent is boarding/living alone.

\subsection{Data Analysis Result}

Table 3. Test result of Direct and Indirect Effects

\begin{tabular}{|l|c|c|}
\hline \multicolumn{3}{|c|}{ Direct Effect ( Direct Effect) } \\
\hline & $\begin{array}{c}\text { T Statistics } \\
(\mid \text { O/STDEV|) }\end{array}$ & P Values \\
\hline $\begin{array}{l}\text { Support_Government -> } \\
\text { Lecturer Performance }\end{array}$ & 3,854 & 0.000 \\
\hline $\begin{array}{l}\text { Government_Support -> } \\
\text { Graduate_Competence }\end{array}$ & 11,435 & 0.000 \\
\hline $\begin{array}{l}\text { Lecturer Performance -> } \\
\text { Competence_Graduates }\end{array}$ & 3,242 & 0.001 \\
\hline $\begin{array}{l}\text { Environment_Family -> } \\
\text { Lecturer Performance }\end{array}$ & 4,671 & 0.000 \\
\hline $\begin{array}{l}\text { Family_Environment -> } \\
\text { Graduate_Competence }\end{array}$ & 3,957 & 0.003 \\
\hline $\begin{array}{l}\text { Environment_University -> } \\
\text { Lecturer Performance }\end{array}$ & 3,222 & 0.001 \\
\hline $\begin{array}{l}\text { Environment_University -> } \\
\text { Graduate_Competence }\end{array}$ & 7,480 & 0.000 \\
\hline \multicolumn{2}{|c|}{ Indirect Effect (Ind direct Effect ) } \\
\hline $\begin{array}{l}\text { Support_Government -> } \\
\text { Lecturer Performance -> } \\
\text { Competence_Graduates }\end{array}$ & 3,233 & 0.000 \\
\hline $\begin{array}{l}\text { Family_Environment -> } \\
\text { Lecturer Performance -> } \\
\text { Graduate_Competence }\end{array}$ & 3,234 & 0.000 \\
\hline $\begin{array}{l}\text { Environment_University -> } \\
\text { Lecturer Performance -> } \\
\text { Competency_Graduates }\end{array}$ & 3,231 & 0.000 \\
\hline
\end{tabular}

\subsection{Discussion}

Based on the results of data analysis, it is known that the variables of the work environment, university environment, job support and lecturer performance have a positive and significant effect on graduate competence, where the significant value is below 0.05. In this study, the learning environment affects the performance of lecturers on the competence of graduates because the online learning environment has supported the teaching and learning process activities. In theory, it states that a good environment will make it easier for lecturers to transfer knowledge to students so that the graduates produced by universities can meet the educational standards required by the government. In this study, it is known that the learning environment carried out by each campus is using zoom media, google meet and other e-learning, especially with the support from the government that helps students such as providing quotas and other assistance so that the teaching and learning process can run well. The learning environment is an important component in a world of education, because the learning environment can directly or indirectly affect the performance of lecturers.

Lecturer performance shows a success in achieving targets or targets within a certain period compared to several targets or targets that have been determined in advance. Competencies of qualified graduates have mastery of academic competencies in the form of hard skills and soft skills as stated in the quality targets and proven by the performance of graduates in the community in accordance with the profession and field of science. This research is in line with research by [21] which concludes that there is a positive and significant influence between the learning environment and the academic achievement of PPKn students in the class of 2008/2009 at Ahmad Dahlan University in the odd semester of the 2011/2012 Academic Year. This can provide input to lecturers and universities that a conducive learning environment will support the teaching and learning process that can improve student achievement.

Graduate competence is also closely related to lecturer performance. Lecturers who are qualified and perform well will certainly carry out their duties and responsibilities well. Likewise, with graduates, qualified graduates are largely determined by the performance of lecturers. For this reason, so that graduates are qualified, graduates must really pay attention to the lecturers seriously during the teaching and learning process.

Jamaluding (2020), stated that the role of the lecturer in addition to being a teacher is also as a researcher and disseminator of information. This means that lecturers' achievements are also determined by the number of papers presented in seminars, writing articles in scientific journals and the preparation of weighty books. In addition, lecturers also need to have the ability to think logically and critically, master research principles and methods and be able to communicate research results. Thus, lecturers are always responsive to the development of science, technology, and social society. This is in line Goldschmidt (2020) research on Lecturer Leadership and Performance in improving the quality of higher education with the conclusion that the level of education quality, leadership, lecturer performance is in the high category or in other words there is a positive and significant relationship. Improving the quality of education will be carried out properly if the planning and evaluation of various management activities that have been carried out within a certain period of time, both in university management management and learning processes and human resource management.

\section{CONCLUSION AND SUGGESTION}

\subsection{Conclusion}

From the result of the data analysis the conclusion are Directly, the family environment, the university 
environment, government support, performance of lecturers has a positive and significant effect on lecturer performance has a positive and significant effect on the competence of graduates and indirectly it is known that lecturer performance is able to mediate all independent family environment, university environment, government support on graduate competence.

\subsection{Suggestion}

It is known that all variables both directly and indirectly have a positive and significant effect. In this case PTS must also pay attention to how the competence of its graduates, the support and influence of the environment are very influential in improving the competence of graduates. During this COVID-19 pandemic, of course, there are many challenges that must be faced, especially with the implementation of online learning, of course, it will make a difficult task for each campus. In this case, there are many learning media provided by the campus such as zoom, google meet and other e-learning media that make it easier for students in the teaching and learning process, as well as assistance that is still provided by the government such as quota subsidies for students which makes students not need to spend money to buy internet packages. Learning environments such as the parental environment and the university environment are also very important in improving the competence of graduates where with a good environment the competence of graduates will increase, universities should provide support to students in the teaching and learning process in this era of the covid 19 pandemic, as well as families who must continue to support so that students who study remain enthusiastic in learning on campus.

\section{AUTHORS' CONTRIBUTIONS}

Ami Dillham Concept Design

Yulinda Literature Review

Fivi Rahmatus Sofiyah Analysis Statistic

\section{ACKNOWLEDGMENTS}

Research Institute in Universitas Sumatera Utara In Accordance With the Talenta Impementation Contract Number of the Universitas Sumatera Utara Fiscal Year 2021 Number: 6789/UN5.1.R/PPM/2021, 16 June 2021

\section{REFERENCES}

[1] Sadikin,Ali dan Afreni Hamidah 2020. Online Learning in the Middle of the Covid-19 Pandemic, BIODIK: Jurnal Ilmiah Pendidikan Biologi, Vol. 06, No. 02,p. 214-224

[2] Jamaludin, D. (2020). Pembelajaran Masa Pandemik Covid-19 Pada Calon Guru. Bandung: UIN Sunan Gunung Jati. Kemendikbud, Kemenag, Kemenkes, \& Kemendagri. (2020). Panduan Penyelenggaraan
Pembelajaran pada Tahun Ajaran 2020/2021 dan Tahun Akademik 2020/2021 di Masa Pandemi Coronavirus Disease.

[3] Anugrahana, A. (2020). Hambatan, Solusi dan Harapan: Pembelajaran Daring Selama Masa Pandemi Covid-19 oleh Guru Sekolah Dasar. Scholaria: Jurnal Pendidikan dan Kebudayaan, Vol. 10, No. 3, 282-289.

[4] Firman, \& Rahman, S. R. (2020). Pembelajaran Online di Tengah Pandemi. Indonesian Journal of Educational Science(IJES), Vol. 2, No. 2, 81-89.

[5] Herliandry, L. D., \& dkk. (2020). Pembelajaran pada Masa Pandemi Covid 19. Jurnal Teknologi Pendidikan, Vol.22, No. 1,65-70.

[6] Abidin, Z, Rumansyah \& Arizona, K. (2020). Pembelajaran Online Berbasis Proyek Salah Satu Solusi Kegiatan Belajar Mengajar di Tengah Pandemi Covid-19. Jurnal Ilmiah Profesi Pendidikan Vol.5, No. 1,64-70.

[7] Saleh, AM.(2020) Problematika Kebijakan Pendidikan di Tengah Pandemi dan Dampaknya terhadap Proses Pembelajaran di Indonesia. https://osf.io/pg8ef/download. (Diakses hari Rabu, 14Oktober 2020)

[8] Long, C. S., Kowang, T.O., Fei. G. C \& Jusch, A. (2016) The linkage of lecturers' competencies and student performance. A case study in Malaysia. The Social Science. (Medwell Journals). Vol 11, No.3, p. 297 300.

[9] Muzenda, A., 2013. Lecturers' competences and students' academic performance, International Journal of Humanities and Social Sciences Invention, Vol.3, No.1,p.6-13.

[10] Gunawan, d. (2020). Variations of Models and Learning Platforms for Prospective Teachers During the COVID-19 Pandemic Period. Indonesian Journal of TeacherEducation, Vol. 1, No. 2,61-70.

[11] Indahri, Y. (2020). Permasalahan Pembelajaran Jarak Jauh di Era Pandemi. Info Singkat: Pusat Penelitian Badan Keahlian DPR RI, Vo. 12, No. 12,13-18.

[12] Gaffar, M. R., \& Septyandi, C. B., 2020. Faktor Yang Memengaruhi Kepuasan Mahasiswa Dalam Menggunakan Media E-Learning Selama Periode Pandemik Corona.Vol. 8, No.1.

[13] Emiyati, A., \& Harming. (2020). Kendala Orang Tua Mendampingi Anak Belajar di Rumah Dalam Menghadapi Situasi Covid 19. Civic-Culture: Jurnal Ilmu Pendidikan PKn dan Sosial Budaya Vol 4,. No. 1 ,8-16.

[14] Dai, D. A. (2020). Online Home Study Plan for Postponed 2020 Spring Semester During the COVID19 Epidemic: A Case Study of Tangquan Middle School in Nanjing, Jiangsu Province, China. Jiangsu, China. 
[15] Hermansyah. (2020). Pembelajaran Daring atau Luring. Dalam G. Indonesia, Pembelajaran Daring EraPandemi (hal. 49-54). Jombang: Delta Pustaka.

[16] Shahzad, A., Hassan, R., Aremu, A. Y., Hussain, A., \& Lodhi, R. N. (2020). Effects of COVID-19 in Elearning on higher education institution students: the group comparison between male and female. Quality and Quantity, 0123456789. https://doi.org/10.1007/s11135-020-01028-z

[17] Fredy, F., Prihandoko, L. A., and Anggawirya, A. M., 2020. The Effect of Learning Experience on the Information Literacy of Students in the Ri-Png Border During Covid-19 Period. International Journal of Multicultural and Multireligious Understanding, Vol.7, No.10, p.171- 180. http://dx.doi.org/10.18415/ijmmu.v7i10.2067

[18] Sharma, K., Deo, G., Timalsina, S., Joshi, A., Shrestha, N., \& Neupane, H. C. (2020). Online learning in the face of COVID-19 pandemic: Assessment of students' satisfaction at Chitwan medical college of Nepal.

[19] Sugiyono, 2017. Metode Penelitian Bisnis Pendekatan Kuantitatif, Kualitatif, Kombinasi dan $R \& D$. Bandung: ALFABETA.

[20] Malhotra, N.K. and Birks, D. (2006) Marketing Research An Applied Approach. 3rd Edition, Prentice Hall, Upper Saddle River.

[21] Ariwibowo, M.S. 2012. Pengaruh Lingkungan Belajar Terhadap Prestasi Belajar Mahasiswa PPKn Angkatan 2008/2009 Universitas Ahmad Dahlan Semester Genap Tahun Akademik 2010/2011. Jurnal Citizenship, 1(2), 113-122.

[22] Goldschmidt, K., \& Msn, P. D. (2020). The Covid Pandemic: Technology Use to Support the Wellbeing of Children. Journal of Pediatric Nursing , 3-5. 